ÇOMÜ Uluslararası Sosyal Bilimler Dergisi 3 (2), 389-406 , 2018

COMU International Journal of Social Sciences 3 (2), 389-406, 2018

\title{
Kurumsal İletişim Bağlamında Belediyelerde Kurumsal Twitter Hesabı Kullanımı
}

\author{
Sadık SAYILGANOĞLU *
}

Öz

Sosyal medya uygulamaları, iletişimde kolaylık sağlaması, hızlı ve düşük maliyetli olması nedeniyle günümüzde belediyeler tarafından kurumsal olarak yaygın bir biçimde kullanılmaktadır. Bununla birlikte, belediyelerin halkla iletişim kurması, talep, öneri ve eleştirilerini alarak bu bilgiler 1şığında kurumsal stratejilerini belirlemesi gibi faaliyetler, bir sosyal medya uygulaması olan kurumsal Twitter hesabıyla daha aktif bir düzeye ulaştırılabilir. Bu çalışmada belediyelerin kurumsal Twitter hesaplarını kullanım biçimleri belirlenerek daha etkin kullanım yöntemleri geliştirilmeye çalışılmıştır. Bu amaçla Esenyurt Belediyesi, Küçükçekmece Belediyesi ve Bağcılar Belediyesi kurumsal Twitter hesapları üzerinde 01.02.201828.02.2018 tarihleri arasında içerik analizi yöntemiyle araştırma yapılmış, elde edilen sonuçlar karşılaştırılarak çözüm önerileri sunulmaya çalışılmıştır. Çalışmanın genel sonuçlarına göre, kurumsal Twitter hesaplarında sorunları ileten, bilgi talep eden bir iletişim anlayışı öne çıkmakla birlikte, hesaplardaki üye sayısı dikkate alındığında bu iletişimin sınırlı düzeyde olduğu da görülmektedir. Ayrıca kurumsal Twitter hesaplarının, genel anlamda katılımın ilk evresinde olduğu gibi sadece bilgi aktarma faaliyeti gösteren ve doğrudan katılımı teşvik etmeyen biçimde kullanıldığı tespit edilmiştir.

Anahtar Kelimeler: Kurumsal İletişim, Halkla İlişkiler, Sosyal Medya, Twitter, Belediye.

\section{Use of Corporate Twitter Account in Municipalities in the Context of Corporate Communication}

\begin{abstract}
Social media applications are widely used by municipalities today because of their ease of communication, fast and cost-effective. However, activities such as municipalities communicating with the public, taking demand, suggestions and
\end{abstract}

* Doktora Öğrencisi, İstanbul Aydın Üniversitesi, İletişim Fakültesi, Halkla İlişkiler ve Tanıtım Bölümü, sadiksayilganoglu@hotmail.com 
criticisms and determining their corporate strategies in the light of this information can be reached more actively with the corporate Twitter account, which is a social media application. In this study, the methods of using corporate Twitter accounts of municipalities were determined and more effective methods of using them were tried to be developed. For this purpose, the content analysis method was carried out on the corporate Twitter accounts of Esenyurt Municipality, Küçükçekmece Municipality and Bağc1lar municipality between 01.02.2018-28.02.2018 and the results obtained were compared to the results and the solution proposals were tried to be presented. According to the general results of the study, although a communication approach that transmits problems in corporate Twitter accounts and demands information emerges, it is also observed that this communication is limited when the number of members in the accounts is taken into consideration. In addition, it has been determined that corporate Twitter accounts are used only as in the first phase of participation in general, in a way that shows information transfer activity and does not encourage direct participation.

Keywords: Corporate Communication, Public Relations, Social Media, Twitter, Municipality.

\section{GİRIŞ}

Sosyal medya kullanımı hem özel hem de kamusal alanlarda hızla yaygınlaşmaktadır. Bu yaygınlaşma, yerelde topluma en yakın konumda bulunan kamu yönetimi birimi olarak belediyeler tarafından da dikkate alınmıştır. Karar alma süreçlerine halkın katılımını sağlamak ve yapılan faaliyetleri etkin bir şekilde duyurulabilmek amacıyla belediyeler tarafından kurumsal sosyal medya kullanımının yaygınlık kazandığı görülebilmektedir (Tarhan, 2012: 77).

Sosyal medyanın insan hayatının önemli bir parçası haline geldiği günümüzde, yerel yönetimlerin halkla ilişkiler ve iletişim anlayışı da önemli ölçüde değişim göstermektedir. Belediyelerin toplumla olan iletişimlerini kurumsal sosyal medya hesapları üzerinden halkla iletişim kurması, bu şekilde faaliyetlerini halka duyurması dikkate alındığında bu kurumsal hesaplardan paylaşılan mesajların içeriğinin ele alınarak incelenmesi de önem kazanmaktadır. Yerel yönetimlerin kurumsal Twitter hesabına sahip olmaları halkla etkileşimin ilk adımı olarak değerlendirilebilir. Bu ilk adımdan sonra toplum için belediyeler rahatlıkla ulaşabilecekleri, taleplerini iletebilecekleri ve direkt olarak iletişim kurabilecekleri bir yapıya dönüşecek, bu da belediyelerin hizmet kalitesinin artmasını sağlayacak bir faktör olacaktır. Sosyal medya uygulamalarının önemi, özellik ve sonuçları hakkında ilginin gün geçtikçe artmasının yanı sıra, literatür taraması, bu konuda yapılan çalışmaların yetersiz kaldığını göstermektedir. Sosyal medya araçlarının kullanımı yerel yönetimler açısından kurumsal iletişim ve halkla ilişkiler noktasında önem arz etmektedir. Bu konuda yapılacak olan çalışmalar, kurumsal sosyal medya kullanımının önemi, özellik 
ve sonuçları hakkında bilgi sağlayacağından akademik bir değer taşımaktadır. Belediyelerin görev, sorumluluk ve çalışma alanları bakımından halka en yakın kurumsal yapılardan biri olması dikkate alınarak, belediyelerin günlük sosyal medya kullanımları, Kurumsal Twitter hesapları kullanım düzeyleri çalışma kapsamında incelenmektedir. Belediyelerin kurumsal Twitter hesaplarını hangi amaçlar doğrultusunda kullanıldıkları ve kullanım biçimleri belirlenmeye çalışılmaktadır. Bu kapsamda konu içerik analizi yöntemiyle analiz edilerek, iki bölüm halinde ele alınacaktır. İlk bölümde belediyelerin kurumsal sosyal medya kullanımları, kurumsal Twitter hesapları özelinde ele alınarak, kurumsal iletişim ve halkla ilişkiler bağlamında genel bir literatür çalışması sunulmaya çalışılmaktadır. Bu bağlamda tanımı, özellikleri, kullanımı ve bu kullanımın doğası, türleri ayrıca iletişim alanının sosyal medyadan nasıl etkilendiği üzerinde durulmaktadır. İkinci bölüm ise araştırma kısmından oluşmaktadır. Bu bölümde İstanbul'da yer alan nüfus yoğunluğu en fazla ilk üç belediyesi olan Esenyurt Belediyesi, Küçükçekmece Belediyesi ve Bağcılar Belediyesi’nin sosyal medya uygulamalarını kullanım şekilleri ve düzeyleri, kurumsal Twitter hesapları üzerinden analiz edilmektedir. Çalışma kapsamında, Belediyelerin kurumsal Twitter hesaplarını kullanımları 01 Şubat 2018 ile 28 Şubat 2018 tarihleri arasında bir aylık periyotta yapılan paylaşımlar çerçevesinde detaylı olarak izlenmiş ve değerlendirilmiştir.

\section{LITTERATÜR TARAMASI}

Küreselleşmenin etkisini artırdığı günümüzde sosyal medyanın gelişimine paralel olarak halkla ilişkiler ve iletişim alanlarında da küreselleşmenin etkisi net bir şekilde görülmektedir. Kurumların halkla ilişkilerden sorumlu birimleri sosyal medyadaki bu değişim ve dönüşüme ayak uydurmak için daha hızlı ve aktif davranmalı ve sosyal medya uygulamalarını kullanırken çift yönlü iletişimi dikkate alarak diyalojik bir yaklaşımla, daha interaktif ve sosyal sorumluluk anlayışı ile hareket etmeleri gerekmektedir. $\mathrm{Bu}$ açıdan bakıldığında örgütler, sosyal medya uygulamalarını kullanırken genellikle topluma mesajlarını tek yönlü olarak iletmektedirler. Ancak, sosyal medya uygulamaları, kurumsal karar alma mekanizmaları içerisinde karar alma süreçlerini etkileyen, katılımcı yönetim anlayışını geliştiren, toplum ile kurum arasında bilgi akışını ve etkileşimi sağlayan stratejik bir araç niteliğindedir (Şimşek, 2016: 831).

Siyasal iletişimin kişilerarası boyutunun dışında, dijital iletişim teknolojileri de siyasal iletişim sürecinde kullanılan iletişim araçları arasındaki payını her geçen gün arttırmaktadır. Dijital iletişim teknolojileri içerdiği yeniliklerle siyasal iletişim sürecinde aktörlere geleneksel medyadan farklı olanaklar sunmakta, bu anlamda yeni medya olarak kendine dair beklentileri de arttırmaktadır (Çetin, 2015: 90).

Sosyal medya uygulamalarını içinde barındıran dijital iletişim teknolojileri, topluma kazandırdığg yenilikler ile siyasal iletişim süreci içerisinde siyasal aktörlere yeni imkanlar sunmaktadır. Bu imkanlar iletişimin devamlılığı noktasında geleceğe dönük yeni stratejiler geliştirilmesini de teşvik etmektedir. Bu durum da doğal olarak dijital medya teknolojisinden beklentilerin artmasına neden olmaktadır (Yılmaz, 2008: 123). 
Sosyal medya uygulamaları yakın tarihimizde ortaya çıkmış oldukça yeni iletişim araçlarındandır. Bu sebeple konuyla alakalı araştırma yapılması ve bilgi birikiminin artması, bu uygulamaların özellikleri ve sonuçları bakımından önem arz etmektedir. Bilimsel bir yöntem ve çalışmayla bu konu üzerinde araştırma yapılarak, sonuçlarının ortaya konulması akademik bir değer taşımaktadır. Bu tarz bir ilgi üzerine 2016 yılında yapılmış olan bir çalışmada, görevleri ve sorumlulukları icabı halkla sürekli yakın iletişim içerisinde olan ve bu iletişimi sosyal medya uygulamaları üzerinden gerçekleştiren büyükşehir belediye başkanlarının kişisel sosyal medya hesaplarını kullanım düzeyleri günlük olarak ele alınmak suretiyle değerlendirilmiştir. İçerik analizi yöntemiyle incelenen kurumsal Twitter hesaplarının hangi amaçlara yönelik olarak ve hangi düzeyde kullanıldı̆̆ belirlenmeye çalışılmıştır. Yapılan çalışma sonucunda ise büyükşehir belediye başkanları içerisinde Melih Gökçek'in kişisel sosyal medya hesaplarını, özellikle Twitter hesabını en etkin kullanan başkan olduğu ortaya çıkmış, bunun yanı sıra, başkanların Twitter ve diğer sosyal medya hesaplarını genel olarak çalışmalarını, kurumsal etkinliklerini takipçilerine duyurma amaçı kullanıldıkları sonucuna varılmıştır (Arslan, 2016: 1374).

Her ne kadar çift yönlü etkin iletişim düzeyine ulaşılmamış olsa da, çoğu yerel yönetimin sosyal medya araçlarını kullandığı bilinmektedir. Şeffaflığı arttırmak, sosyal medya yoluyla iletişim kurmayı teşvik etmek açısından bu önemli ancak, genel olarak kurumsal iletişim ve e-katılım hala gelişme aşamasındadır (Bonson vd., 2012: 123).

İletişim oluşturma bağlamında, sosyal medyanın, e-katılımı teşvik etmek için ümit vaat edici bir araç olarak değerlendirilmesine rağmen, e-katılımın faydalarının henüz, mevcut zorluklar nedeniyle tam olarak gerçekleşmediğini göstermektedir (Gibby vd., 2014: 2). Belediyelerin, sosyal medya adaptasyonunun, katılımcılık anlayışından daha çok internet siteleri aracılığıyla geleneksel hizmetlerine aracılık ettiğini görmek mümkündür (Lidén ve Larsson, 2016: 339).

Sosyal medya kullanımına, bu konuda yapılan çalışmalar çerçevesinde bakıldığın da, siyasal iletişim için internet kanalının kullanımının artmasının, politikayı etkilemek için diğer kanallarla erişime sahip sivil toplum organizasyonlarının elini kuvvetlendirdiği sonucunu ortaya koymaktadır. Dijital politikalar, yeterli kaynakları harekete geçirebildikleri sürece, yeni aktörleri ve belki de politik tartışmalarda yeni sesleri ortaya çıkarmaya da yardımcı olabilir. (Scaramuzzino ve Scaramuzzino, 2017, 46). Sosyal medya, halkın katılım stratejisiyle bütünleştirilmeli, bu da daha sonra genel bir kamu yönetimi stratejisine dönüştürülmelidir (Agostino, 2013: 234).

Geseule, Metallo ve Longobardi 287 İtalyan ve İspanyol belediyesinin bilgi yayınlama konusundaki tutumunu web sitesi üzerinden inceleyerek dijital iletişimin temel etmenlerini belirlemek için, analiz etmiştir. Bulgular; Belediyelerin internet görünürlüğü, zenginlik ve çevresel faktörlerin dijital iletişimin düzeyini belirlemede önemli bir rol oynadığını göstermektedir (Geseule vd., 2017: 1).

Özellikle yerel yönetimlerde sosyal medyanın kamu sektöründe yarattığı etkiyi anlamak 
için yeterli çalışma mevcut değildir. Sosyal medya yerel yönetime önemli faydalar ve fırsatlar sunsa da, sosyal medyanın etkisi ile ilgili araştırmalar yetersiz kalmaktadır. $\mathrm{Bu}$ boşluğu gidermek için, yapılan bir araştırmada, Dang-Xuan ve arkadaşları yerel yönetimlerde sosyal medya etkisinin belirleyicilerinin bir modelini öne sürmektedirler. Model, sosyal medya kullanan 173 Avustralya yerel yönetim örgütü ile yapılan bir anketle toplanan verilerle test edilmiştir. Araştırma sonucu; algılanan faydalar, algılanan güvenlik riskleri, uyumluluk ve formülizasyonun derecesini içeren faktörlerin, yerel yönetimlerde sosyal medya etkisinin belirleyici unsurları olduğunu göstermektedir. Ayrıca, Twitter uygulaması üzerinden seçim dönemleri boyunca, etkili hesap özellikleri ve iletişim davranışları geliştirerek, bu uygulamanın politik iletişim amacıyla kullanılmakta olduğu sonucuna ulaşılmıştır (Dang-Xuan, vd., 2013: 795).

Belediyeler sosyal medya teknolojilerini genellikle tanıtım, halkla ilişkiler ve olumlu kurumsal imaj oluşturma amaçlı kullanmaktadır (Bennett ve Manoharan, 2017: 325). Ayrıca Twitter diğer sosyal medya uygulamaları ile karşılaştırıldığında daha çok sürekli diyalog için kullanıldığı görülmektedir (Enli ve Skogerbø, 2013: 757).

Sosyal medya uygulamalarının, halkla ilişkiler alanında ilişki yönetiminin bir unsuru olarak kabul edilen ve çift yönlü iletişim modeli ile ilişkilendirilen diyalojik iletişim kuramı temelinde değerlendirilmesi ayrıca önem arz etmektedir. 2013 yılında yapılan araştırma kapsamında, Ankara Büyükşehir Belediyesine ait kurumsal sosyal medya uygulamaları diyalojik kuram ilkelerine uygunluğu bakımından içerik analizi yöntemiyle ele alınmış, Belediyenin kurumsal Twitter uygulaması diyalojik kriterler başlığı altında incelenmiştir. Yapılan inceleme sonucunda; Belediyenin kurumsal sosyal medya uygulamaları iletişimin diyalojik ilkelerine uygunluk düzeyi bakımından yeterli bulunmasa da kurumsal Twitter hesabı, diğer kurumsal sosyal medya uygulamaları içerisinde, iletişim açısından en başarılı uygulama olduğu değerlendirilmiştir (Yağmurlu, 2013: 95). Sosyal medya, yerel yönetimlere vatandaşlarla ilişki kurabilmek için çeşitli firsatlar sunmaktadır (Omar vd., 2014: 666). Sosyal medya bir monolitik grup değildir ve karmaşık etkileşimlere görev ve örgütsel bağlamda daha fazla araştırma yapılmasını gerektirir (Oliveira ve Welch, 2013: 397).

Sosyal medyanın açıklığı ve şeffaflı̆̆ı arttırmak, kamuoyunda daha iyi bir fikir sahibi olmak, e-katılım kavramını teşvik etmek, vatandaşlara mesajları iletmek ve düşük maliyetle birçok kullanıcıya ulaşmak için kullanabilecek uygun araçlar olduğu görülmektedir (Alasem, 2015: 67).

Sosyal ağlar, yerel yönetimlerin vatandaşlarla iletişim kurma biçimlerini değiştirerek karar alma süreçlerine katılmalarını teşvik etmektedir. Avrupalı yerel yönetimler kendi vatandaşlarıyla ilişkilerini kurmak ve geliştirmek için Twitter hesapları üzerinden diyaloğa girme stratejileri geliştirmekte ve daha sonra bunları uygulamaya geçirmektedir. Ancak yerel yönetimler paydaşlarla çevrimiçi ilişkiler kurarken iletişimsel prensiplerin kullanılmasıyla elde edilen faydalardan çoğunlukla haberdar değildir. Bu nedenle, yerel yönetimlerin vatandaşlarla diyaloğa dayalı iletişimi güçlendirmek için kurumsal Twitter 
hesaplarını daha etkin kullanmaları gerekmektedir (Martín vd., 2015: 421).

Gerek bireysel gerekse kurumsal olarak mesaj göndermeye imkan sağlayan Twitter, teknik açıdan, tweet, retweet, replies ve hashtags bileşenlerden oluşan Twitter, hem toplumu bir takım faaliyetlerle ilgili bilgilendirme de bir araç olarak kullanılabilir hem de halkın talep, öneri, soru, şikayet ve eleştirilerinin öğrenilerek çözüm üretilmesine ve üretilen çözümün toplumla paylaşılmasına imkan sağlayabilir (Tarhan, 2012: 82).

Twitter vatandaşlarla daha yakın bir ilişki kurabilmeyi sağlamakta ve buna ortam oluşturmaktadır (Graham, vd., 2013: 692). Bunun yanı sıra bir dijital iletişim aracı olarak Twitter, iletileri daha yüksek mekansal ve zamansal çözünürlükte, daha hızlı ve daha düşük maliyetle sunabilmektedir (Sánchez vd., 2017: 829).

Twitter platformu üzerinde vatandaşı ilgilendiren bir hususta insanlar düşüncelerini ifade edebilir ve aynı sanal ortamda buluşabilir. Yeni medya teknolojisinin sunduğu etkileşimsel özellik, toplumun karşılıklı etkileşimine zemin hazırlayarak bu platformları kamusal bir ortama dönüştürebilir (Çetin, 2015: 94).

Japonya'da meydana gelen deprem felaketinde Tsukuba yerel yönetimi halkla iletişim sağlamak için, Twitter uygulamasını etkin bir şekilde kullanmıştır. Twitter platformu, felaket süresi boyunca Tsukuba yerel yönetimi tarafından topluma haber aktarması açısından önemli rol oynamıştır (Kaigo, 2012: 19). Bu durum sosyal medyanın yerel yönetimler açısından önemini göstermektedir.

2012 yılında Türkiye'de dokuz büyükşehir belediyesi’ne ait kurumsal Twitter hesabı üzerinde yapılan araştırma kapsamında 3302 tweet içerik analizi yöntemiyle ele alınmış, araştırma sonucunda; değerlendirmeye alınan büyükşehir belediyelerinin kurumsal Twitter hesaplarından gönderilen mesajların daha çok kurumsal faaliyetler, altyapı çalışmaları, sosyal ve kültürel etkinlikler ile alakalı olduğu tespit edilmiştir. Bunun yanı sıra, yapılan araştırma sonucunda, değerlendirmeye tabi olan dokuz büyükşehir belediyesinin kurumsal twitter hesaplarını toplumu bilgilendirme ve duyuru amaciyla kullandıkları görülmüştür (Tarhan, 2012: 76).

Türkiye'de 22 belediyeye ait kurumsal Twitter hesabı üzerinde yapılan bir araştırma kapsamında içerik analizi yöntemi ile incelenme yapılmış, araştırma sonucuna göre, Twitter hesaplarında problemleri ileten ve bilgi talep eden bir etkileşimin ön plana çıktığı görülmüştür. Bunun yanı sıra, Twitter hesaplarındaki takipçi sayıları dikkate alındığında etkileşim düzeyinin sınırlı olduğu tespit edilmiş olup, Twitter hesaplarının daha çok bilgi aktarmak amacıyla kullanıldığı sonucuna varılmıştır (Memiş, 2015: 209).

Yapılan bir tez çalışması kapsamında Konya merkez ilçe belediyeleri kurumsal sosyal medya hesapları ele alınarak, bu belediyelerin sosyal medya platformlarını kullanış biçimleri, hangi halkla ilişkiler modeli çerçevesinde faydalandıkları içerik analizi yöntemiyle incelenerek belirlenmeye çalışılmıştır. Araştırma sonucunda; belediyelerin 
sosyal medya uygulamalarını tanıma ve tanıtma amaçlı olarak kullandıkları, ancak, halkla ilişkiler açısından bakıldığında ise her iki yönden de yetersiz olduğu görülmüştür. Belediyelerin, kurumsal Twitter hesaplarını, çoğunlukla toplumu bilgilendirme biçiminde tek yönlü olarak kullandıkları belirlenmiştir (Şenyurt, 2015: 44).

Mehmet Zahid Sobacı ve Naci Karkın tarafından 2013 yılında yapılan bir çalışmada, Türkiye'deki belediye başkanlarının Twitter uygulamasını kullanım biçimleri içerik analizi yöntemiyle incelenmiş ve Twitter'ın özellikle kendini tanıtma, politik pazarlama, faaliyetler hakkında bilgi paylaşma ve kişisel mesajlar gönderme ve benzeri kullanım şekillerinin benimsendiği sonucuna varılmıştır (Sobaci ve Karkin, 2013: 417).

Çalışma kapsamında yapılan literatür taraması neticesinde elde edilen bilgiler, kurumsal sosyal medya hesapları kullanım ve etkileșim düzeylerinin belirlenmesi noktasında, başta kurumsal Twitter hesabı olmak üzere kurumsal sosyal medya hesaplarının, halkla ilişkiler ve iletişim bağlamında araştırılmasının önem arz ettiğini ortaya koymaktadır.

\section{ARAŞTIRMA}

Çalışmada, İstanbul'un nüfus yoğunluğu en fazla üç ilçe belediyesi olan Esenyurt Belediyesi, Küçükçekmece Belediyesi ve Bağcılar Belediyesi’ne ait kurumsal Twitter hesapları içerik analizi yöntemi ile ele alınarak incelenmiștir. İçerik analizi ile 01.02.2018 - 28.02.2018 tarihleri arasında belediyelerin kurumsal Twitter hesapları üzerinden yapılan paylaşımlar mesaj içeriği, aldıkları beğeni, retweet ve yorum sayıları tespit edilmiş, yorumlar olumlu, olumsuz ve nötr olması bakımından ele alınmış, bu kapsamda toplam 289 tweet incelenmiştir. Araştırma da elde edilen veriler, sosyal bilimler için istatistik proğramı olan SPSS proğramında analiz edilerek grafikler oluşturulmuştur. Daha sonra bu grafiklerden ortaya çıkan sonuçlar, sorular ve varsayımlar çerçevesinde değerlendirilmiştir. Yazınsal ve görsel içeriklerin çözümlenmesinde yaygın olarak içerik çözümlemesi tekniğinin kullanılıyor olması, belediyelerin kurumsal Twitter hesaplarında birden fazla kategori bulunması ve iletilerin farklı yönleriyle incelenmesi, bu çalışmanın içerik analizi yöntemi ile değerlendirilmesini gerekli kılmıştır.

Bu çalışmanın temel amacı, üç ilçe belediyesine ait kurumsal Twitter hesaplarının kullanım şekilleri ve kullanım düzeylerinin, halkla ilişkiler ve kurumsal iletişim bağlamında belirlenmesi üzerinedir. Bu bağlamda, elde edilen bulgular ışığında belediyelere kurumsal Twitter hesaplarını daha etkin ve verimli kullanmalarını sağlayacak tavsiyelerde bulunmak ve fikirler sunmak, ayrıca bu alanda daha sonra yapılacak çalışmalara ışık tutacak bilgilerin ortaya konması da amaçlanmaktadır.

Araştırmanın sınırlılıkları bakımından, İstanbul'da nüfus yoğunluğu en fazla üç ilçe belediyesi olan Esenyurt Belediyesi, Küçükçekmece Belediyesi ve Bağcılar Belediyesi çalışma kapsamında üzerinde incelemede bulunulan temel sınırlılık olup, bu belediyelerin kurumsal sosyal medya uygulamalarından kurumsal Twitter hesaplarından yapilan bir aylık paylaşımlar ve bu uygulama içerisinde bulunan diğer öğeler üzerinden incelenmesi, 
çalışmanın evrenini belirleyen sınırlılıklardandır.

\subsection{Literatür Taraması Kapsamında Oluşturulan Araştırma Soruları.}

S1 : Belediyeler kurumsal Twitter hesaplarını halkla İlişkiler ve iletişim bağlamında etkin olarak kullanmaktamıdır?

S2 : Belediyeler kurumsal Twitter hesaplarını daha çok hangi amaçlarla kullanmaktadır?

S3: Belediyeler arasında kurumsal Twitter hesaplarını kullanma düzeyi ve şekli bakımından farklılıklar varmıdır?

S4 : Belediyeler kurumsal Twitter hesaplarını vatandaşların yönetime katılımını sağlayacak şekilde diyalojik bir yaklaşımla kullanmaktamıdır?

S5 : Belediyelerin kurumsal Twitter hesapları vatandaşlarla etkin iletişim sağlayarak karar alma süreçlerine katılımı teşvik edebilmektemidir?

\subsection{Araştırma Soruları Kapsamında Oluşturulan Araştırma Hipotezleri.}

H1: Belediyeler kurumsal Twitter hesaplarını daha çok gerçekleştirdikleri kurumsal çalışmalar hakkında kamuyu bilgilendirme amacı ile kullanmaktadır.

H2: Belediyeler kurumsal Twitter hesaplarını vatandaşların yönetime katılımını sağlayacak biçim olan diyalojik yaklaşımla kullanmaktadır.

H3: Kurumsal Twitter hesapları kullanım düzeyi ve kullanım şekli bakımından Belediyeler arasında farklılıklar bulunmaktadır.

H4: Belediyeler kurumsal Twitter hesaplarını halkla ilişkiler ve kurumsal iletişim bağlamında etkin bir şekilde kullanmaktadır.

H5: Belediyelerin kurumsal Twitter hesapları vatandaşlarla iletişim kurma biçimini değiştirerek karar alma süreçlerine katılımı teşvik etmektedir.

H6: Belediyelerin kurumsal Twitter hesapları üzerinden çok paylaşımda bulunmak, hesap takipçi sayısının artmasına neden olmaktadır. 
Tablo: 1 Belediyelerin Twitter Hesap Adı, Gönderi ve Takipçi Sayıları.

\begin{tabular}{|l|l|l|l|l|}
\hline Sıra & Adı & Hesap Adı & $\begin{array}{l}\text { Tweet } \\
\text { Sayıları }\end{array}$ & $\begin{array}{l}\text { Takipçi } \\
\text { Sayıları }\end{array}$ \\
\hline 1 & Esenyurt Belediyesi & https://twitter.com/EsenyurtBLDYS & 59 & 79200 \\
\hline 2 & Küçükçekmece Belediyesi & https://twitter.com/Kucukcekmecemiz & 175 & 17200 \\
\hline 3 & Bağcılar Belediyesi & https://twitter.com/BagcilarBld & 55 & 27200 \\
\hline
\end{tabular}

Örneklemde 1 Şubat 2018 - 28 Şubat 2018 tarihleri arasında üç ilçe belediyesi kurumsal Twitter hesaplarından toplam 289 tweet paylaşmışlardır. Paylaştıkları toplam tweet sayıları ve toplam takipçi sayıları incelendiğinde (Tablo 1) en çok Küçükçekmece Belediyesi 175 adet gönderi paylaşmıştır. İkinci olarak Esenyurt Belediyesi 59 adet gönderi paylaşmış ve az bir farkla Bağcılar Belediyesi 55 adet gönderi paylaşımıyla Esenyurt Belediyesini takip etmiştir. 1 Mart 2018 tarihinde tespit edilen takipçi sayılarına göre, Esenyurt Belediyesi 79200 takipçi sayısıyla birinci sırada yer almış, O’nu 27200 takipçi sayısıyla Bağcılar Belediyesi takip etmiş, Küçükçekmece Belediyesi ise 17200 takipçi sayısıyla son sırada yer almıştır. En çok paylaşımda bulunan Küçükçekmece Belediyesinin en az takipçi sayısına sahip olduğu dikkate alındığında, çok sayıda paylaşımda bulunmanın takipçi sayısını artırmadığı ortaya çıkmaktadır. Bu sonuçlara göre, belediyelerin kurumsal sosyal medya hesabı kullanımlarında, halkla ilişkiler bağlamında stratejik iletişime yönelmeleri ve bunu kalıcı hale getirmeleri gerektiği ifade edilebilir. Kurumların, iletişim anlayışlarını çağın koşullarına uygun biçimde belirlemeleri, bu alanda başarılı olabilmeleri için önem arz etmektedir.

\section{Şekil 1: Paylaşımların Belediyelere Göre Yüzdesel Dağılımı.}

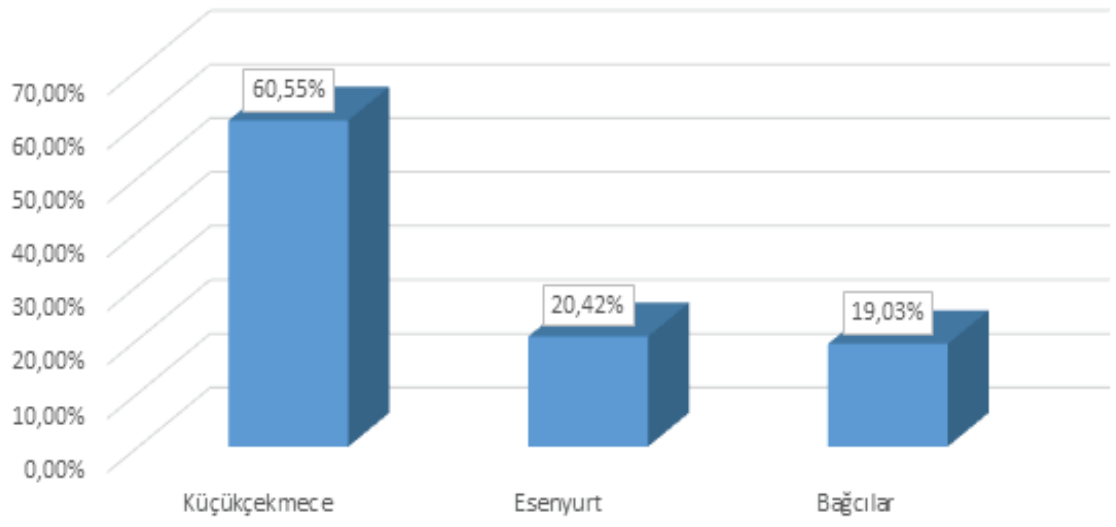


Örneklem kapsamındaki süreç içerisinde belediyelerin toplam paylaşım oranlarının yüzdesel dağılımına bakıldığında (Şekil 1) Küçükçekmece Belediyesi \%60,55 (175) oranla ilk sırada, Esenyurt Belediyesi \%20,42 (59) oranla ikinci ve Bağcılar Belediyesi \%19,03 (55)'lük paylaşım oranıyla üçüncü sırada yer almıştır. Bu oranlar, belediyelerin kurumsal Twitter hesapları kullanım düzeylerinin farklı olduğunu göstermektedir.

\section{Şekil 2: Belediyelerin URL, Mention ve Hashtag Gönderi Oranları.}

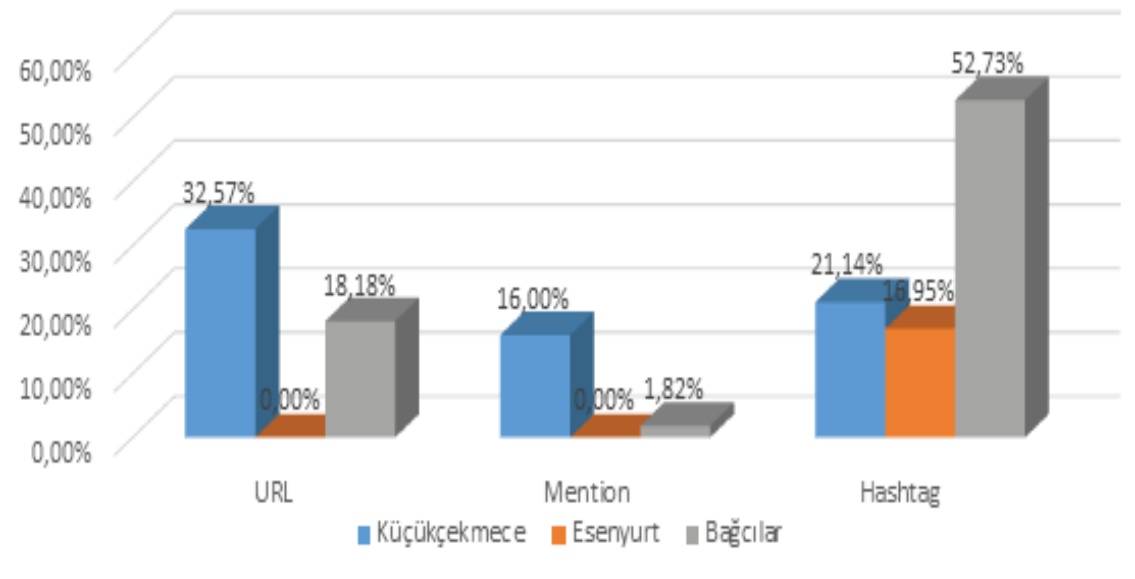

Belediyelerin URL, Mention ve Hashtag pratikleri incelendiğinde (Şekil 2) Kurumsal Twitter hesabı takipçilerini paylaşmış oldukları internet sitelerine yönlendirmek amacıyla URL paylaşımında bulunduğu gözlemlenmiştir. Twitter'da 140 karakter sinırlaması bulunması nedeniyle kullanıcılar bu özelliği tercih etmektedirler. Belediyelerin paylaşımlarına URL içeriği açısından baktığımızda, Küçükçekmece Belediyesi \%32,57 (57) oranla birinci, Bağcılar Belediyesi \%18,18 (10) oranla ikinci sırada yer almış ve Esenyurt Belediyesi paylaşımlarında URL kullanmamışlardır. Belediyelerin paylaşımlarını Mention içeriği açısından ele aldığımızda Küçükçekmece Belediyesi \%16,00 (28) oranla URL paylaşımında olduğu gibi açık ara birinci sırada yer almış, sonrasında Bağcılar Belediyesi \%1,82 (1) oranda kalırken Esenyurt Belediyesi paylaşımlarında Mention kullanmamışlardır. Hashtag içeriği bakımından değerlendirdiğimizde ise Bağcılar Belediyesi \%52,73 (29) oranla ilk sırada yer alırken, Küçükçekmece Belediyesi \%21,14 (37) oranla o'nu takip etmiş ve Esenyurt Belediyesi \%16,95 (10) oranla son sırada yer almıștır. $\mathrm{Bu}$ veriler $1 s ̧ ı$ ğında değerlendirdiğimizde Küçükçekmece Belediyesi bu teknik özellikleri en fazla kullanan belediye olurken, onu üç teknik özelliği de çok düşük oranda kullanan Bağcılar Belediyesi takip etmiş, Esenyurt Belediyesi ise iki özelliği hiç kullanmazken sadece Hashtag özelliğini çok düşük bir oranla kullanmıştır. Etkileşim düzeyini artırma açısından Mention uygulaması önemli görülmektedir. Mevcut verilere göre, belediyelerin bu uygulamadan çok fazla istifade etmedikleri, toplumla etkin iletişim kurmadıkları ve toplumun yönetime katılımını sağlayacak şekilde diyalojik bir yaklaşım sergilemedikleri 
ortaya çıkmıştır.

Şekil 3: Belediyelerin Fotoğraf, Video ve Metin Gönderi Oranları.

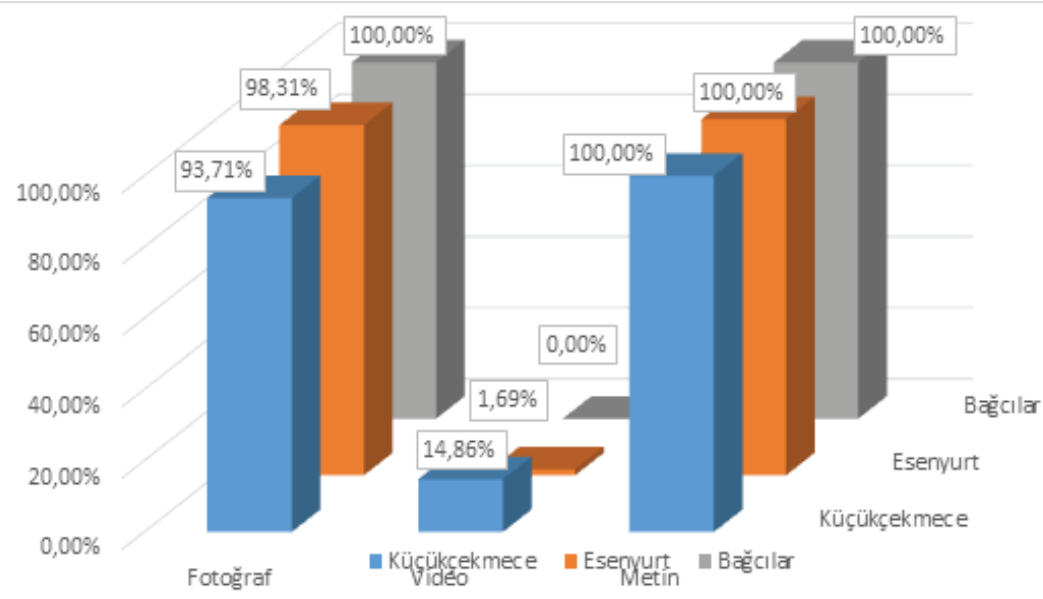

Belediyeler, yapmış oldukları paylaşımların (Şekil 3) tamamında metin kullanmışlardır. Ayrıca paylaşımlarının tamamına yakınında fotoğraf kullanmış oldukları da grafikte görülmektedir. Video paylaşımı yönünden ise belediyeler çok fazla yoğunluk göstermemiş, genel olarak video paylaşım düzeyleri üç belediyede de düşük oranda kalmıştır. Belediyeler mesajlarını topluma iletirken en fazla düz gönderi ve fotoğraf yoluyla bu mesajları aktarmaya çalışmışlardır. Her ne kadar belediyeler arasında kurumsal Twitter hesapları kullanım düzeyi ve kullanım şekli bakımından bazı farklılıklar bulunsa da, genel olarak benzer özellikler taşıdıkları görülmektedir.

Şekil 4: Belediyelerin Almış Oldukları Beğeni, Retweet ve Yorum Oranları.

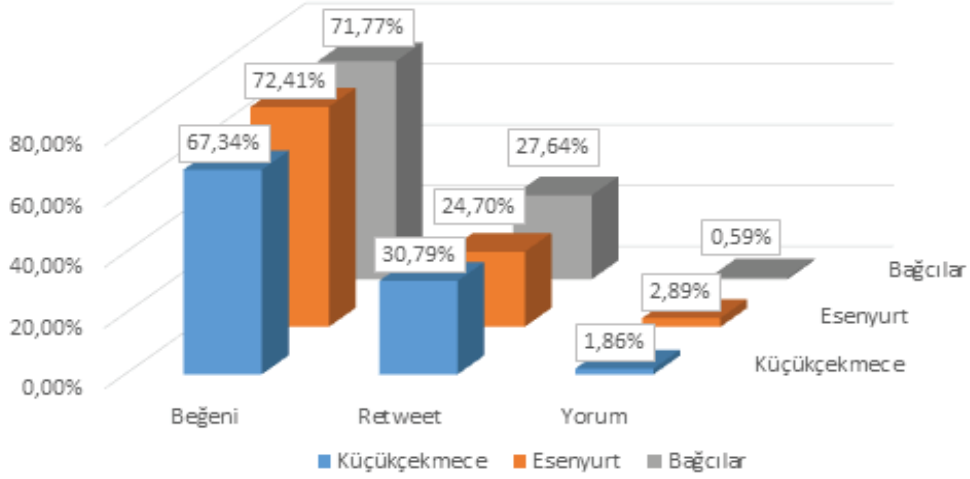


Yapılan paylaşımların etkileşim ve geri dönüşüm açısından sonuçlarını daha net bir şekilde görebilmemizi sağlayacak Beğeni, Retweet ve Yorum içeriği yönünden değerlendirdiğimizde (Şekil 4) Esenyurt belediyesi \%72,41 beğeni oranıla ilk sırada yer alırken, retweet olarak Küçükçekmece belediyesi \%30,79'la en yüksek orana sahip olmuş ve yorum bakımından ise yine Esenyurt belediyesi \%2,89'luk oranla ilk sırada yer almıştır. Her ne kadar belediyelerin paylaşımlarına aldıkları Beğeni oranları yüksek olsa da, Retweet, özelliklede Yorum oranlarının son derece düşük olması, tek yönlü bir iletişim anlayışının hakim olduğunu göstermektedir. Bu nedenle belediyelerin toplumla etkileşim kurmada zayıf kaldığı, çift yönlü iletişim açısından iyi bir noktada bulunmadığ 1 ve karar alma süreçlerine toplumun katılımını sağlayacak ve teşvik edecek bir yaklaşım ortaya koyamadıkları söylenebilir.

\section{Şekil 5: Belediyelerin almış oldukları yorumların Olumlu, Olumsuz ve Nötr oranları.}

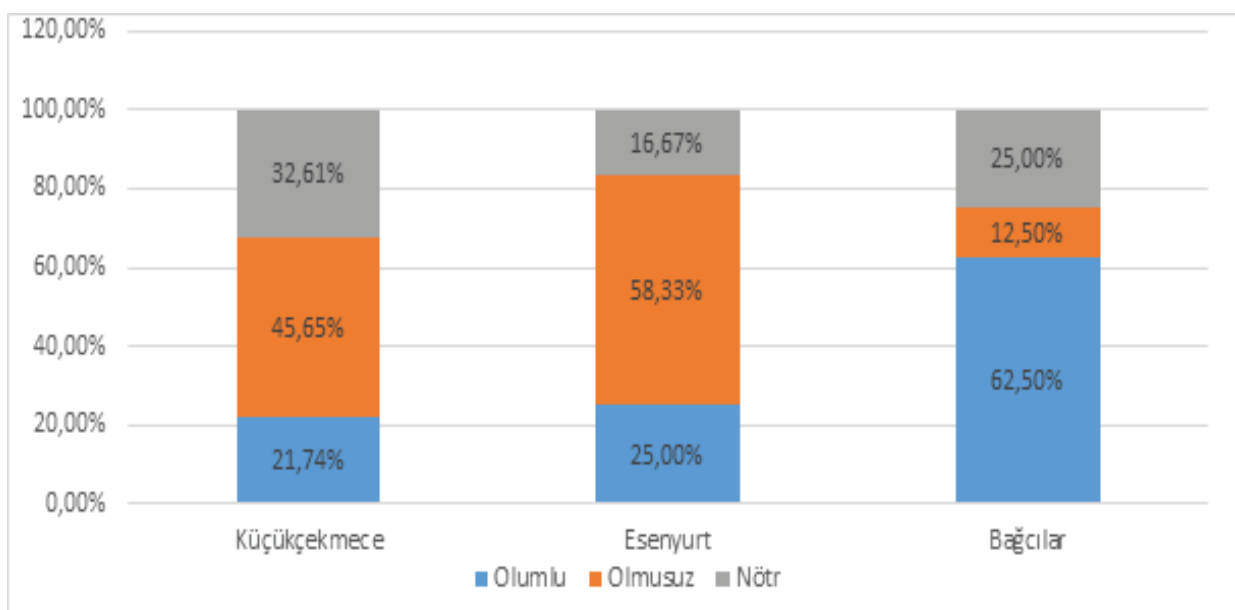

Belediyelerin paylaşımlarına yapılan yorumları içerik yönünden (Şekil 5) olumlu, olumsuz ve nötr olarak analiz edecek olursak, en düşük yorum oranına sahip Bağcilar Belediyesi \%62,50 olumlu oranıyla ilk sırada yer alırken, Esenyurt Belediyesi \%25,00, Küçükçekmece Belediyesi \%21,74'lük oranlarda olumlu yorum almışlardır. Paylaşımlara yapılan olumsuz ve nötr yorumlar Bağcılar Belediyesi dışında, diğer iki belediye için, yapılan olumlu yorumlardan daha fazla orana sahiptir. Paylaşımlara alınan yorumlarda Bağcrlar Belediyesinin düşük oranda kalması, Küçükçekmece ve Esenyurt Belediyesinin ise olumsuz ve nötr oranlarının olumlu oranından daha fazla olması dikkate alındığında, kurumsal Twitter hesaplarının, toplumun düşünce, ihtiyaç, talep ve önerilerinin etkin bir biçimde alınarak değerlendirildiği bir platform olma düzeyine henüz ulaşmadığı, ayrıca vatandaşın katılımını sağlayacak şekilde kullanılmadığı sonucu ortaya çıkmaktadır. Bunun yanı sıra elde edilen bu veriler çerçevesinde, belediyelerin kurumsal Twitter hesaplarını kullanım amaçları ve yaklaşımlarının, sonuçlara etkisi bakımından belirleyici rol oynadığı görülmektedir. 


\section{Şekil 6: Küçükçekmece Belediyesinin Paylaşımlarının, Konulara Göre Dağılımı}

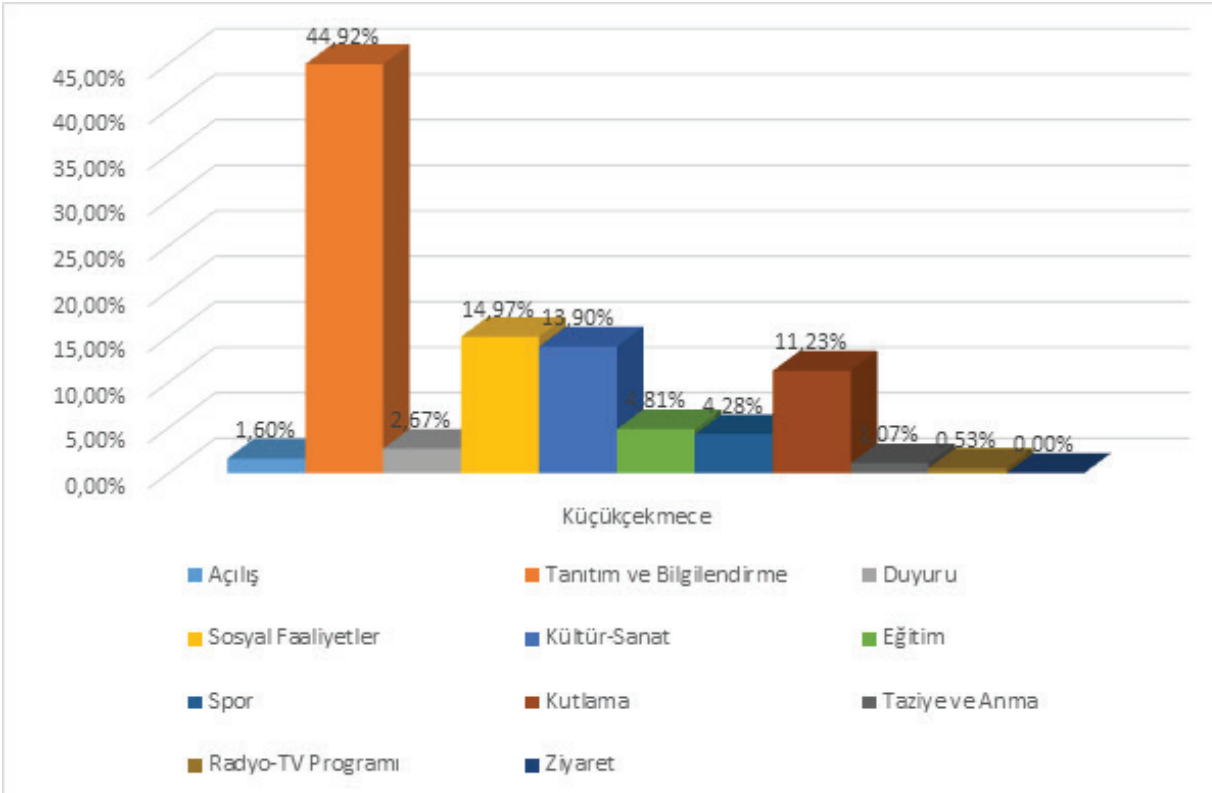

Küçükçekmece Belediyesinin paylaşımlarının konulara göre dağılımına baktığımızda (Şekil 6) \% 44,92 oranında Tanıtım ve Bilgilendirme konusunda paylaşımda bulunduğu, diğer konularda ise paylaşımların bu oranın çok altında olduğu görülmektedir. Paylaşımların konulara göre dağılımının bir noktada yoğunlaşması ve belirli konularda ağırlık kazanması, bu uygulamanın belediyeler tarafından çok yönlü bir iletişim anlayışıyla kullanılmadığını ortaya çıkarmaktadır. Ayrıca, kurum ile halk arasında sağlanması gereken etkin iletişim imkanını da zayıflatmaktadır. Bu açıdan değerlendirdiğimizde kurumsal Twitter hesabının kullanış biçiminin, toplumla etkileşim düzeyini artırmaktan ziyade, toplumu yapılan çalışmalardan haberdar etme yaklaşımına sahip olduğu ortaya çıkmaktadır. Bu da belediyeler kurumsal Twitter hesaplarını daha çok, gerçekleştirdikleri kurumsal çalışmalar hakkında kamuyu bilgilendirme amacı ile kullanmaktadır varsayımımızı desteklemektedir. 


\section{Şekil 7: Esenyurt Belediyesinin Paylaşımlarının, Konulara Göre Dağılımı.}

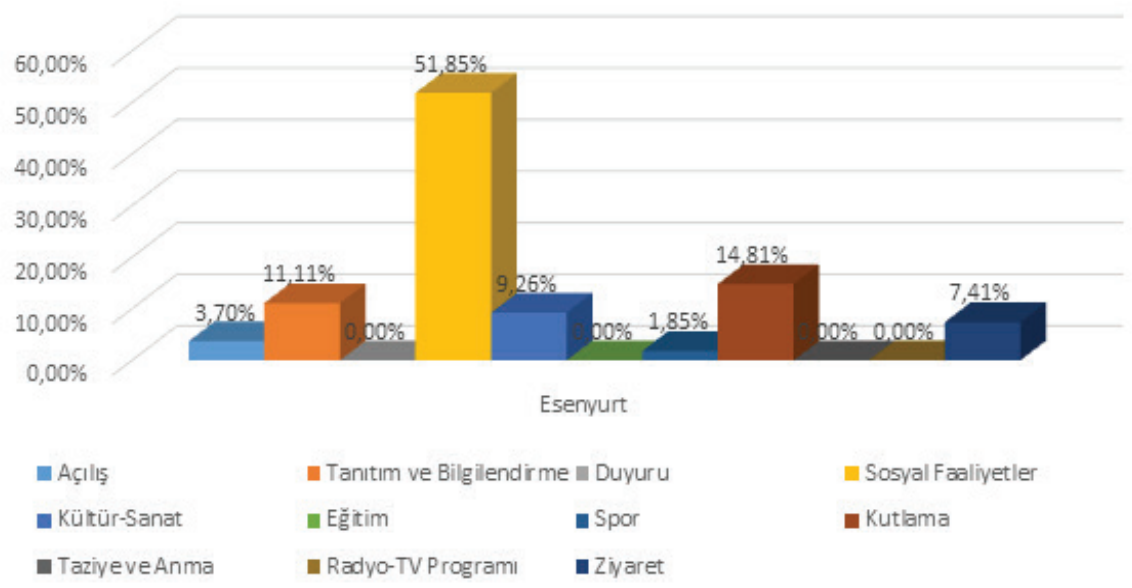

Esenyurt Belediyesinin kurumsal Twitter hesabı paylaşımları konularına göre (Şekil7) dağılımına bakıldığında sosyal faaliyetler içeriğinin \%51,85'le en yüksek orana sahip olduğu görülmektedir. Yapılan paylaşımların konulara göre dağılımı noktasında, belediyeler arasında kurumsal Twitter hesabını kullanış biçimi ve yaklaşım olarak farklılıklar bulunmaktadır. Ancak, Tweet sayısının azlığı, Mention kullanmamış olması, Retweet ve Yorum oranlarının düşük seviyede bulunması, Esenyurt Belediyesinin kurumsal Twitter platformunu etkin bir iletişim aracı olarak kullanamadığını bize göstermektedir.

\section{Şekil 8: Bağcılar Belediyesinin Paylaşımlarının, Konulara Göre Dağılımı.}

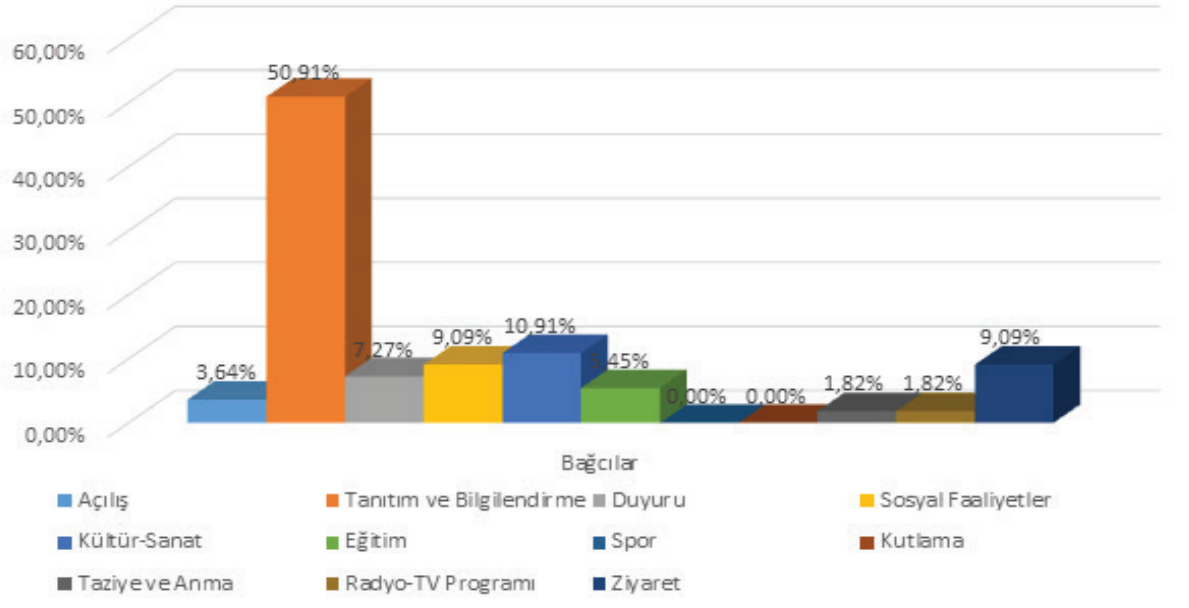


Bağcılar Belediyesinin kurumsal Twitter hesabı paylaşımlarının konulara göre (Şekil 8) dağılımı, yine \%50,91 oranda en yüksek Tanıtım ve Bilgilendirme konusunda yapılmıştır. Yukarıda ifade edilen Küçükçekmece Belediyesi paylaşım oranlarının benzerleri burada da görülebilmektedir. Üç belediyenin kurumsal Twitter hesaplarında, faaliyet bilgilerini topluma ulaştırma amaçlı tek yönlü iletişim anlayışının hakim olduğu bir durum karşımıza çıkmaktadır.

\section{SONUÇ}

Belediye halkla ilişkiler birimlerinde geleneksel iletişim uygulamalarının yerini online iletişim araçları, kurumsal sosyal medya uygulamaları almıştır. Online iletişim ve halkla ilişkiler çerçevesinde değerlendirildiğinde bu uygulamalar, belediyelerin geleneksel iletişim uygulamalarına göre, daha hızlı ve daha ucuz halkla iletişim imkanı sunmaktadır. Kurumsal Twitter hesapları, kurumsal sosyal medya uygulamalarından bir tanesidir. Toplumun günümüzde sosyal medyayı kullanım oranı ve kullanma yoğunluğu arttıkça, kurumsal iletişim stratejilerinin de bu platformlar üzerinden geliştirilmesini gerekli kılmaktadır. Araştırma kapsamı dahilinde bulunan belediyelerin kurumsal Twitter hesapları incelemesinin genel sonuçlarına bakıldığında, paylaşılan iletiler, içerik olarak birbirinden farklı konularda yoğunlaşmakta olup, bu da belediyelerin bu hesapları farklı biçimlerde ve farklı amaçlarla kullandıklarını ortaya çıkarmaktadır. Ayrıca belediyelerin bir aylık paylaşımlarının analiz edilmesi neticesinde, belediyelerin her ne kadar Twitter hesabı kullanımlarında tweet, retweet, beğeni ve yorum düzeylerindeki etkinlik ve yoğunluk oranları farklılık gösterse de, çift yönlü iletişimin tam olarak uygulanamaması açısından aynı özelliklere sahip oldukları görülmektedir.

Belediyelerin kurumsal Twitter hesaplarını kullanımları açısından değerlendirildiğinde; belediyeler, kurumsal Twitter hesaplarını daha çok yapmış olduğu hizmet ve faaliyetlerin tanıtımı ve halkı bilgilendirme amacı doğrultusunda kullanıldığı, halkla etkileşim kurma noktasında ise, yeterli oranda faydalanılmadığı sonucuna ulaşılmıştır

Belediyeler kurumsal Twitter hesaplarını etkin kullandığında, belediye hizmetlerinin toplum merkezli yürütülmesi ve kaliteli hizmet üretimini sağlayacak çift yönlü iletişim süreçlerini beraberinde getirecektir. Belediyelerin yapmış olduğu hizmet ve faaliyetler hakkında halkı bilgilendirmek, halkın görüş, talep, eleştiri ve önerilerini alma açısından kurumsal Twitter hesapları, kurum ile toplum arasında çift yönlü iletişim ve etkileşimin gelişmesine olanak sağlayacaktır. Bu sosyal medya platformu üzerinden toplumun yönetim ve karar alma süreçlerine katılımını sağlamak, iletişimi çift yönlü hale dönüştürmek ve vatandaşın her türlü talep, öneri, şikayet ve yorumlarını alabilmek için, paylaşılan iletilerin daha çok soru içerikli olması tavsiye edilmektedir. 


\section{KAYNAKÇA}

Agostino, D. (2013). Using social media to engage citizens: A study of Italian municipalities. Public Relations Review, Volume 39, Issue 3, 232-234. https://doi.org/10.1016/j. pubrev.2013.02.009.

Alasem, A. (2015). E-government on twitter: The use of twitter by the saudi authorities. The electronic journal of e-government, Volume 13 Issue 1, 67-73. http://www.ejeg.com (Erişim: 22.03.2018).

Arslan, Ş. (2016). Yerel politikacıların sosyal medya kullanımı: Büyükşehir belediye başkanlarının günlük sosyal medya kullanımlarının incelenmesi. Uluslararası Sosyal Araştırmalar Dergisi, Cilt: 9, Sayı: 42, 1374-1391.

Bennett, L.V.; Manoharan, A. P. (2017). The use of social media policies by us municipalities. International Journal of Public Administration, Volume 40, Issue 4, 317-328. https:// doi.org/10.1080/01900692.2015.1113182.

Bonson, E.; Torres. L.; Royo, S.; Flores, F. (2012). Local e-government 2.0: Social media and corporate transparency In municipalities. Government İnformation Quarterly, Journal home, Volume 29, Issue 2, 123-132. https://doi.org/10.1016/j.giq.2011.10.001.

Çetin S. (2015). Yerel seçimlerinde büyükşehir belediye başkan adaylarının twitter kullanımları üzerine karşılaştırmalı analiz. Global Media Journal TR Edition, 5 (10) spring 2015, 87-120.

Dang-Xuan, L.; Stieglitz, S.; Wladarsch, J.; Neuberger, C. (2013). An invastigation of influentials and the role of sentiment in political communication on twitter during election periods. Journal Information, Communication \& Society, Volume 16, Issue 5, 795-825. https://doi.org/10.1080/1369118X.2013.783608.

Enli, G. S.; Skogerbø, E. (2013). Personalized campaings in party-centered politics twitter and facebook as arenas for political communication. Information Communication \& Society, 16 (5), 757-774. http://dx.doi.org/10.1080/1369118X.2013.782330.

Geseule, B.; Metallo, C.; Longobardi, S. (2017). The determinants of e-disclosure attitude: Empirical evidences from İtalian and Spanish municipalities, İnternational Journal of Public Administration, https://doi.org/10.1080/01900692.2017.1300917.

Gibby, A.; Smith, S.; Pang, V.; Toorn, C. V. (2014). The impact of web 2.0 (GOV 2.0) and social media technologies on engagement in local government. Association for Information Systems AIS Electronic Library, PACIS 2014 Proceedings, Paper 120. http://aisel.aisnet.org/pacis. (Erişim: 23.04.2018).

Graham, T.; Broersma, M.; Hazelhoff, K.; Haar, G.V. (2013). Bettween broadcasting political messagess and interacting with voters. Information, Communication \& Society, Volume 16, Issue 5, Pages 692-716. https://doi.org/10.1080/1369118X.2013.785581.

Kaigo, M. (2012). Social media usage during disasters and social capital: Twitter and the great east Japan earthquake. Keio Communication Review, No:34, 19-35. http:// 
www.mediacom.keio.ac.jp/publication/pdf2012/KCR34_02KAIGO.pdf.

(Erișim: 09.04.2018).

Lidén, G.; Larsson, A. O. (2016). From 1.0 to 2.0: Swedish municipalities online. Journal of Information Technology \& Politics, Volume 13, Issue 4, 339-351. https://doi.org/10. 1080/19331681.2016.1169242.

Martín, A. S.; Rosario, A.H.; Pérez, M. C. C. (2015). Using twitterfor dialogic communication: Local government strategies in the european union. journal local government studies, Volume 41, Issue 3, 421-444. https://doi.org/10.1080/03003930.2014.991866.

Memiş, L. (2015). Yerel e-katılımın yeni aracı olarak sosyal ağlar: Facebook ve twitter örnekleri. Çankırı Karatekin Üniversitesi İktisadi ve İdari Bilimler Fakültesi Dergisi, Cilt 5, Sayı 1, 209-249.

Oliveira, G. H. M.; Welch, E. W. (2013). Social media use in local government: Linkage of technology, task, and organizational context. Government Information Quarterly journal, Volume 30, Issue 4, 397-405. https://doi.org/10.1016/j.giq.2013.05.019.

Omar, K.; Stockdale, R.; Scheepers, H. (2014). Social media use in local government: An Australian perspective. International Journal of Public Administration, Faculty of Business and Enterprise, Swinburne University, Australia, Volume 37, Issue 10, 666675. https://doi.org/10.1080/01900692.2014.903270.

Sánchez, C. R.; Craglia, M.; Bregt, A. K. (2017). New data sources for social indicators: the case study of contacting politicians by twitter. International Journal of Digital Earth, Volume 10, 2017 - Issue 8, 829-845. https://doi.org/10.1080/17538947.2016.1259361.

Scaramuzzino, G.; Scaramuzzino, R. (2017). The weapon of a new generation? Swedish civil society organizations' use of social media to influence politics. Journal of Information Technology \& Politics, Volume 14, Issue 1, 46-61. https://doi.org/10.1080 /19331681.2016.1276501.

Sobaci, M. Z.; Karkin, N. (2013). The use of twitter by mayors in Turkey: tweets for better public services?. Government Information Quarterly journal, Volume 30, Issue 4, 417 425. https://doi.org/10.1016/j.giq.2013.05.014.

Şenyurt, G. (2015). Belediyelerin halkla ilişkiler uygulamalarında internetin ve sosyal medyanın kullanımı: Konya merkez ilçe belediyeleri üzerine bir inceleme. Yayımlanmamış yüksek lisans tezi, Selçuk Üniversitesi Sosyal Bilimler Enstitüsü, Konya.

Şimşek, G. (2016). Büyükşehir belediye başkanlarının diyalojik iletişim çerçevesinde sosyal medya uygulamaları. Uluslararası Sosyal Araştırmalar Dergisi, Cilt: 9, Sayı: 46, 829-839.

Tarhan, A. (2012). Büyükşehir belediyelerinin sosyal medya uygulamalarına halkla ilişkiler modellerinden bakmak. Ankara: İletişim Kuram ve Araştırma Dergisi, Sayı 35 /Güz, 76-97. 
Yağmurlu, A. (2013). Diyalojik iletişim çerçevesinden Ankara büyükşsehir belediyesi sosyal medya uygulamaları. Selçuk İletişim Dergisi, Cilt: 8, Sayı: 1, 95-115.

Yılmaz, M. (2008). Politik iletişim sürecinin dijital iletişim teknolojisi olarak internet dolayımında kurgulanmasi: Yeni olanaklar, stratejiler ve beklentiler. Yayımlanmamış doktora tezi, Ege Üniversitesi Sosyal Bilimler Enstitüsü, İzmir. 